\title{
Enzyme-Encapsulated Liposome-Linked
}

\author{
Immunosorbent Assay Enabling Sensitive Personal
}

\section{Glucose Meter Readout for Portable Detection of}

\section{Disease Biomarkers}

Bingqian Lin, Dan Liu, Jinmao Yan, Zhi Qiao, Yunxin Zhong, Jiawei Yan, Zhi Zhu, Tianhai Ji, Chaoyong James Yang*

State Key Laboratory of Physical Chemistry of Solid Surfaces, The MOE Key Laboratory of Spectrochemical Analysis \& Instrumentation, Collaborative Innovation Center of Chemistry for Energy Materials, Key Laboratory for Chemical Biology of Fujian Province, and Department of Chemical Biology, College of Chemistry and Chemical Engineering, Affiliated Chenggong Hospital, Xiamen University, Xiamen 361005, P. R. China.

* To whom correspondence should be addressed. Tel: (+86) 592-218-7601; Fax: (+86) 592-2189959. E-mail: cyyang@xmu.edu.cn 
The sequences of oligonucleotides employed in this assay are given below:

Capture probe:

5'- TTT TTT TTT TTT GGT TGG TGT GGT TGG - biotin - 3'

Detection probe:

5' - lipo - TTT TTT TTT TAG TCC GTG GTA GGG CAG GTT GGG GTG ACT - 3’

Synthesis of Lipid Phosphoramidite

$\overbrace{\mathrm{NH}_{2}}^{\mathrm{Stearoyl} \text { chloride }} \underset{\mathrm{ClCH} \mathrm{CH}_{2} \mathrm{Cl}}{\mathrm{HO}_{\mathrm{HO}}}$

1

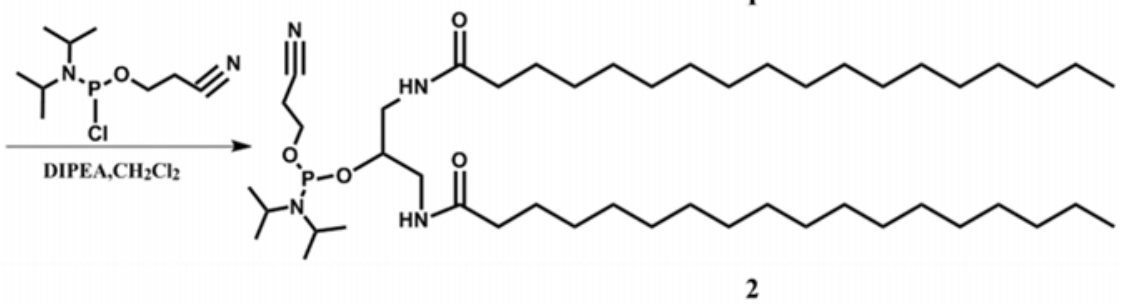

Scheme S1. The synthesis procedure of lipid phosphoramidite.

As shown in Scheme S1, the lipid phosphoramidite was prepared according to the progress reported by Tan's group with slight modifications.1

Synthesis of compound 1. $0.5 \mathrm{~g}$ (5.55 mmol) 1,3-diamino-2-dydroxypropane and $1.45 \mathrm{~g}$ (11.21 mmol) TEA were dissolved in $50 \mathrm{~mL} \mathrm{ClCH} 2 \mathrm{CH} 2 \mathrm{Cl}$ as solution A. $3.39 \mathrm{~g}(11.21 \mathrm{mmol})$ stearoyl chloride was dissolved in $25 \mathrm{~mL} \mathrm{ClCH} 2 \mathrm{CH} 2 \mathrm{Cl}$ as solution $\mathrm{B}$. The solution $\mathrm{B}$ was added dropwise to the solution A and then stirred for $2 \mathrm{~h}$ at $\mathrm{RT}$ and $70^{\circ} \mathrm{C}$ overnight. Afterwards, the solution was 
cooled to RT and filtered followed by washing with $\mathrm{CH} 2 \mathrm{Cl} 2, \mathrm{CH} 3 \mathrm{OH}, 5 \% \mathrm{NaHCO} 3$ and ethyl ether. The product was dried under vacuum to get compound 1 as a white solid. The characterization data are as below.

1H NMR (300 MHz, CDCl3): $\delta 6.3(\mathrm{~m}, 2 \mathrm{H}), 3.8(\mathrm{~m}, 1 \mathrm{H}), 3.4-3.2(\mathrm{~m}, 4 \mathrm{H}), 2.2(\mathrm{t}, 4 \mathrm{H}), 1.6(\mathrm{~m}$, $4 \mathrm{H}), 1.3-1.2(\mathrm{~m}, 60 \mathrm{H}), 0.9(\mathrm{t}, 6 \mathrm{H})$.

Synthesis of compound $2.3 \mathrm{~g}(4.82 \mathrm{mmol})$ compound 1 was added to a dry round-bottom flask and cooled on an ice bath. Anhydrous CH2Cl2 (52 mL), DIPEA (2.2 mL, $9.63 \mathrm{mmol})$, and 2Cyanoethyl N, N-diisopropylchlorophosphoramidite $(2.2 \mathrm{~mL}, 9.63 \mathrm{mmol})$ were added under dry nitrogen. The solution was stirred at RT for $1 \mathrm{~h}$ and heated to $60^{\circ} \mathrm{C}$ for 90 minutes. After cooling to RT, the solution was dried to change solvent from $\mathrm{CH} 2 \mathrm{Cl} 2$ to ethyl acetate. Afterwards, the solution was washed with $5 \% \mathrm{NaHCO} 3$ and brine, then dried over $\mathrm{Na} 2 \mathrm{SO} 4$ and concentrated under vacuum. The solution was then added $\mathrm{CH} 3 \mathrm{COCH} 3$ to precipitate the product at $-20^{\circ} \mathrm{C}$ for $4 \mathrm{~h}$. The product was washed with $\mathrm{CH} 3 \mathrm{COCH} 3$ twice and dried under vacuum as a white solid. The characterization data are as below.

1H NMR (300 MHz, CDCl3): $\delta 6.4(\mathrm{~m}, 2 \mathrm{H}), 3.9(\mathrm{~m}, 2 \mathrm{H}), 3.8(\mathrm{~m}, 2 \mathrm{H}), 3.6(\mathrm{~m}, 2 \mathrm{H}), 3.0-2.9(\mathrm{~m}$, 2H), $2.6(\mathrm{t}, 2 \mathrm{H}), 2.2(\mathrm{~m}, 4 \mathrm{H}), 1.6(\mathrm{~m}, 6 \mathrm{H}), 1.3-1.2(\mathrm{~m}, 72 \mathrm{H}), 0.9(\mathrm{t}, 6 \mathrm{H})$.

31P NMR (CDCl3) 154 ppm.

\section{Preparation of Liposomes}

Liposomes were prepared by thin lipid film-hydrated method. 


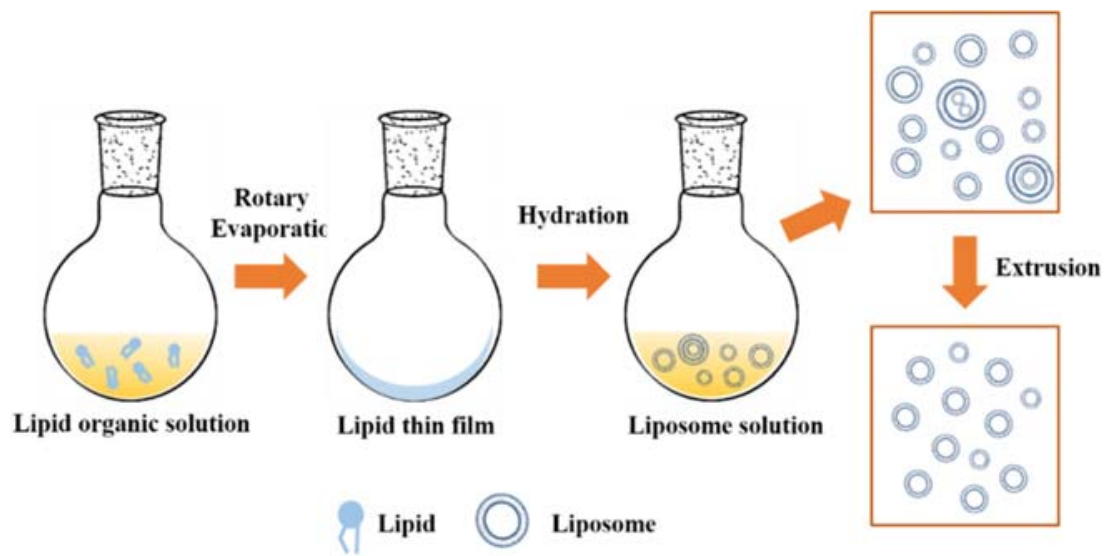

Scheme S2. The synthesis procedure of liposomes by thin lipid film-hydrated and extrusion method.

\section{Preparation of Functionalized MBs.}

Immobilization of biotinylated aptamers. The biotinylated aptamers immobilization was following the protocol of Dynabeads ${ }^{\circledR}$ MyOne $^{\mathrm{TM}}$ Streptavidin C1. $500 \mu \mathrm{L}$ streptavidin coated magnetic beads was washed by $1 \mathrm{~mL}$ buffer ( $5 \mathrm{mM}$ Tris-HCl, $0.5 \mathrm{mM}$ EDTA, $1 \mathrm{M} \mathrm{NaCl}, \mathrm{pH} 7.5$ ) for two times and the supernatant was removed by a magnet. Resuspend beads in $500 \mu \mathrm{L}$ buffer (10 mM Tris-HCl, $1 \mathrm{mM}$ EDTA, $2 \mathrm{M} \mathrm{NaCl}, \mathrm{pH}$ 7.5) and add an equal volume of $2.5 \mathrm{nmol}$ biotinylated DNA in distilled water. The solution was mixed thoroughly by vortexing and incubated $15 \mathrm{~min}$ at room temperature using gentle rotation. After that, the supernatant was removed by a magnet and the beads were washed three times with buffer ( $5 \mathrm{mM}$ Tris-HCl, 0.5 mM EDTA, $1 \mathrm{M} \mathrm{NaCl}$, pH 7.5). Resuspend beads in $500 \mu \mathrm{L}$ buffer (Tris $20 \mathrm{mM}, \mathrm{KCl} 5 \mathrm{mM}, \mathrm{NaCl}$ $\left.140 \mathrm{mM}, \mathrm{MgCl}_{2} 1 \mathrm{mM}, \mathrm{pH} 7.5\right)$ and store at $4^{\circ} \mathrm{C}$. 
Anti-CRP conjugation of tosylactivated MBs. The CRP antibody conjugation was following the protocol of Invitrogen Dynabeads ${ }^{\circledR}$ M-280 Tosylactivated. A portion of 5 mg Dynabeads M-280 tosylactivated magnetic beads $(165 \mu \mathrm{L})$ was washed by $1 \mathrm{~mL}$ buffer $(0.1 \mathrm{M}$ PBS buffer, $\mathrm{pH}$ 7.4) for two times and the supernatant was removed by a magnet. Then the beads were added $200 \mu \mathrm{L}$ of $500 \mu \mathrm{g} / \mathrm{mL} \mathrm{CRP}$ antibody and $50 \mu \mathrm{L}$ buffer $\left(3 \mathrm{M}\left(\mathrm{NH}_{4}\right)_{2} \mathrm{SO}_{4}\right.$ in $0.1 \mathrm{M}$ PBS buffer, $\mathrm{pH}$ 7.4). The solution was mixed thoroughly by vortexing and incubated on a roller at $37^{\circ} \mathrm{C}$ for 12 hours. After that, the supernatant was removed by a magnet and the beads were added with $1 \mathrm{~mL}$ buffer (PBS buffer with $0.5 \% \mathrm{BSA}, \mathrm{pH} 7.4$ ), incubated at $37^{\circ} \mathrm{C}$ for 1 hour on a roller. After that, the supernatant was removed and the beads were washed for two times (PBS buffer with 0.1\% BSA, pH 7.4) and dispersed in $240 \mu \mathrm{L}$ buffer (PBS buffer with $0.5 \% \mathrm{BSA}, \mathrm{pH} 7.4$ ) by vortexing and stored at $4{ }^{\circ} \mathrm{C}$.

\section{The validation of the influence of surfactant on enzyme activity}

The influence of the surfactant on enzyme activity was tested through the hydrolysis of amylose by amyloglucosidase with and without surfactant. Triton X-100 (1\%) was added to a solution containing $5 \mu \mathrm{L} 3 \mathrm{mg} / \mathrm{mL}$ amyloglucosidase and $30 \mu \mathrm{L} \mathrm{3 \%}$ amylose and was monitored after 5 minutes. As a control, PBS solution, instead of Triton X-100 was added. As shown in Figure S1, the PGM signal was slightly changed (ca 7\%) when added the surfactant. The result indicated that the amyloglucosidase were slightly influenced by surfactant, which has barely influence on the detection assay. 


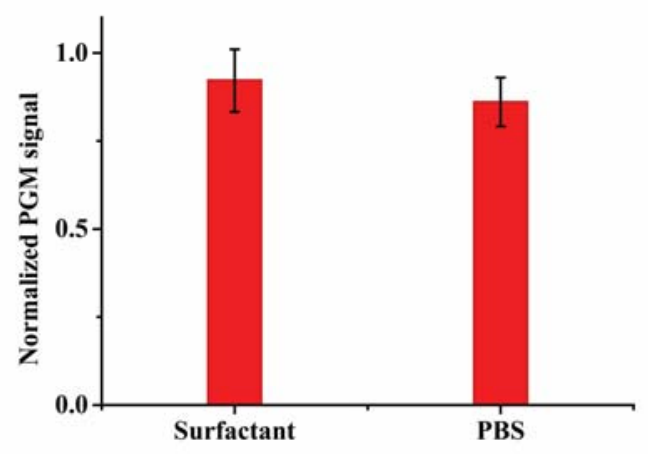

Figure S1. Effect of surfactant on enzyme activity.

\section{Optimization of the Portable Detection Conditions.}

The optimization of concentration. In this assay, the concentration of MBs played a role in the final signal of PGM. To achieve desirable analytical performence, the effect of different concentrations of MBs was investigated. As shown in Figure S2A, the signal of PGM varies gradually as the MBs concentration changing in the range $2-10 \mathrm{mg} / \mathrm{mL}$. The results indicated that the optimum concentration of MBs used in this assay was $6 \mathrm{mg} / \mathrm{mL}$. The oligonucleotide probes of Detection probe were embedded in the surface of liposomes by hydrophobic effect of lipid that modified in the 5'-end of the probe. To yield a desirable optimization signal, an appropriate concentration of Detection probe is needed. The effect of the concentration of Detection probe was investigated. As shown in Figure S2B, when the concentration is $10 \mu \mathrm{M}$, the oligonucleotide probes are properly embedding in the surface of liposomes, and the free probes are low considering the concentration of liposomes. ${ }^{2}$ Thus, $10 \mu \mathrm{M}$ was selected as the optimum concentration due to its best signal-to-noise level. 


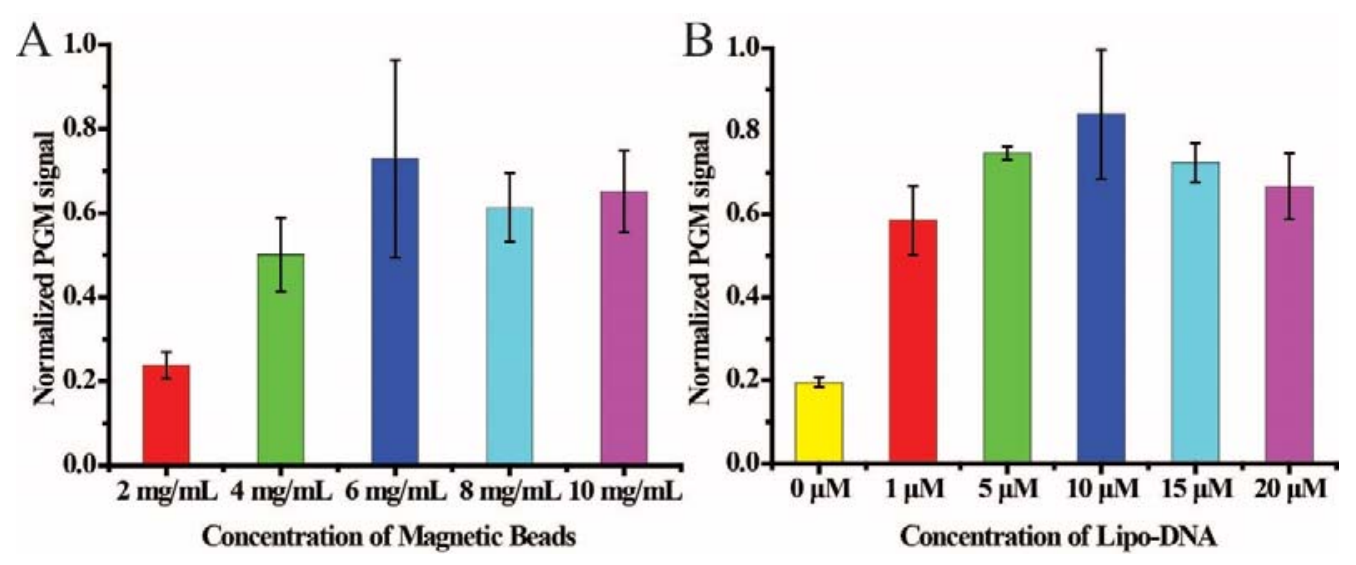

Figure S2. (A) Effect of different concentrations of magnetic beads. (B) Effect of different concentrations of Detection probe.

The optimization of the reaction temperature of glucoamylase. The PGM signal depends heavily on the reaction temperature of glucoamylase with amylose because the enzyme activity relying on the temperature. To evaluate the effect of temperature, different temperatures of amylose hydrosis reaction was carried out. As shown in Figure S3, the signal exhibited a rapid increase when the temperature is above $40^{\circ} \mathrm{C}$. By calculating the best signal-to-noise level, $40^{\circ} \mathrm{C}$ was chosen as the optimum temperature. 


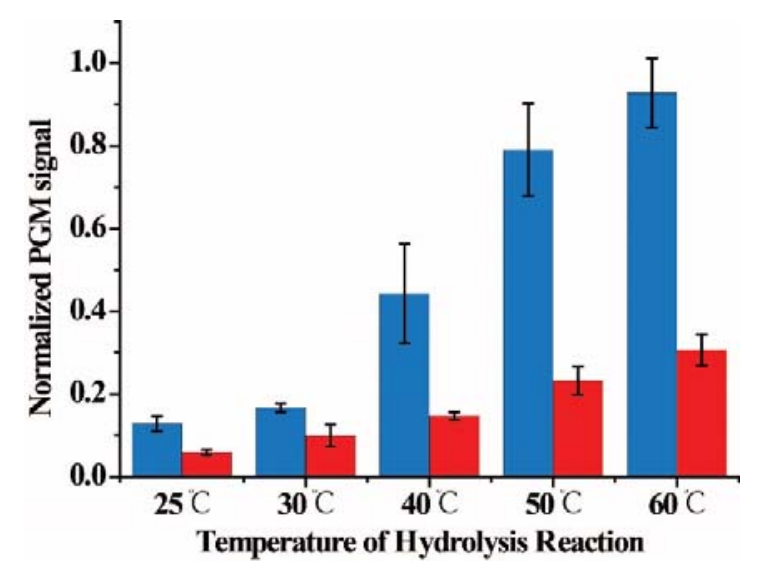

Figure S3. Effect of different temperatures of reaction with amylose.

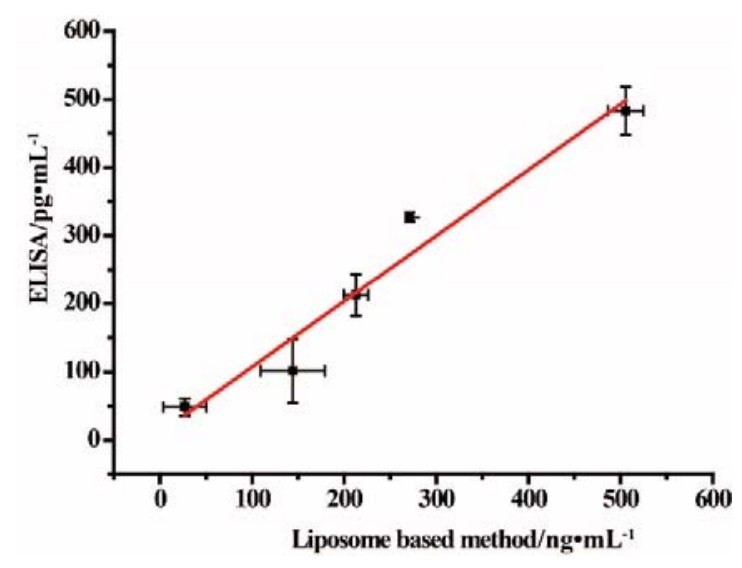

Figure S4. Comparison of the liposome-based method with the traditional ELISA method. 


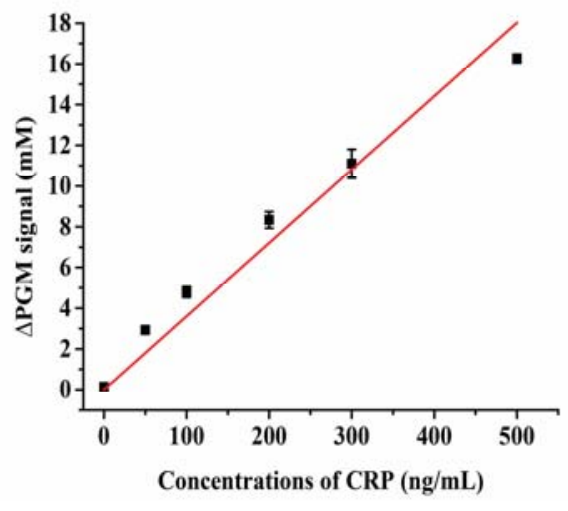

Figure S5. Detection of different concentrations of CRP by liposome-based signal amplification method using PGM in $20 \%$ serum with linear response range from $0 \mathrm{ng} / \mathrm{mL}$ to $500 \mathrm{ng} / \mathrm{mL}$.

\section{REFERENCES}

(1) Liu, H.; Zhu, Z.; Kang, H.; Wu, Y.; Sefan, K.; Tan, W., DNA - Based Micelles: Synthesis, Micellar Properties and Size - Dependent Cell Permeability. Chem. - Eur. J. 2010, 16, 3791-3797.

(2) KANG, H.; O'DONOGHUE, M. B.; LIU, H.; TAN, W., A Liposome-Based Nanostructure for Aptamer Directed Delivery. Chem. Commun. 2010, 46, 249-251. 